\title{
РОЗВИТОК ПУБЛЦИСТИЧНОЇ ДУМКИ В КРАЇНАХ СУБСАХАРІАЛЬНОЇ АФРИКИ
}

\author{
Юрій Мельник \\ Львівський національний університет імені Івана Франка, \\ вул. Генерала Чупринки, 49, 79044, Львів, Україна, \\ e-mail:melnykiurii@gmail.com
}

\begin{abstract}
У статті відтворено основні етапи становлення африканської публіцистичної думки - від перших ідеологів негритюду до ключових ідейно-тематичних трендів сучасності. Серед можливих варіантів вирішення одвічних проблем свого континенту африканські публіцисти виділяють взаємовигідну співпрацю з Китаєм та опору на власні сили (яка включає розвиток громадянського суспільства, громадських інститутів, здатних контролювати владу та впливати на неї). Популярність першої позиції - свідчення успіхів КНР у вмінні застосовувати soft power, бути привабливою альтернативою Заходу, зокрема - на такому багатому на людські та природні ресурси континенті, як Африка. Наявність другої позиції в африканських медіа - свідчення дорослішання африканських суспільств, уміння не шукати винних серед минулих чи сучасних колонізаторів, а брати перш за все на себе відповідальність за невдачі і провали.

Ключові слова: субсахаріальна Африка, африканська публіцистика, африканська література, негритюд, боротьба за незалежність.

Африка - молодий динамічний континент, стратегічне значення якого давно усвідомили ключові геополітичні гравці планети (Китай, США, Індія, Бразилія). Важливість вивчення африканської публіцистики - у дедалі більшому значенні цього континенту (зокрема - субсахаріальної, «чорної» його частини) для майбутнього людства: до 2050 р. кожен четвертий житель планети буде африканцем, а отже зростає вага слова, сказаного творцями громадської думки в Африці; крім того, публіцистичний дискурс Африки має чимало точок дотику із українським (як в історичній перспективі, так і на сучасному етапі), і з огляду на це може бути цікавим для українського журналістикознавства. Мета статті - окреслити парадигму розвитку публіцистичної думки в країнах субсахаріальної Африки.
\end{abstract}

\section{Боротьба за свободу}

Зародження африканської публіцистичної думки сягає корінням у довоєнні часи. В середині 1930-х років у Парижі молодий студент із Мартініки Еме Сезер (22 роки) видає газету L’Etudiant Noir («Чорний студент»), у якій обгрунтовує кон-

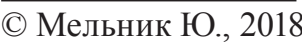


цепцію негритюду (ідею, орієнтовану на самоутвердження африканців та людей африканського походження), закликаючи «плекати наш негритюд як гарне дерево, аж поки воно не принесе найавтентичніші плоди».

«Білі експлуататори дали нам, чорним експлуатованим, культуру, але культуру білу, цивілізацію, але цивілізацію білу, сковуючи нас невидимими кайданами на гіпотетичний випадок, якщо ми визволимося із більш помітного матеріального рабства, у яке вони нас кинули». Тобто: звільнення від видимого, соціально-політичного рабства, як переконує Еме Сезер, не означатиме звільнення, оскільки залишиться культурне рабство, ще більш небезпечніше, оскільки його не легко розпізнати. Саме у зв'язку з цим публіцист полемізує з марксистами, космополітичними революціонерами, які «кажуть негрові повстати, не допомігши йому спершу усвідомити себе, не сказавши йому, що це прекрасно, чудово і законно бути негром» [1].

У цьому ж виданні сенегалець Леопольд Седар Сенгор (28 років) публікує свої перші статті. «Чого ми прагнемо сьогодні? Пробудити расу, якщо вона досі спить*, i кинути їі на боротьбу, яку веде людство проти деструктивних сил. Старій Свропі ми хочемо принести нові елементи гуманності» [4].

Еме Сезер був одним із перших, хто вдихнув у Африку дух непокори загарбникам. «Бути революціонерами, - писав він, - це добре; але для нас, негрів, цього не достатньо; ми не маємо бути революціонерами випадково чорними, а власне революційними неграми, із наголосом на іменнику, як на ключовому слові» [1].

Публіцистам l'Etudiant Noir, інших видань 30-х років (Revue du Monde Noir, Légitime Défense) судилося стати натхненниками зламу у свідомості африканських народів, зачинателями нового, африканоцентричного типу мислення, відповідно до якого африканець не соромиться себе, а пишається собою, своїм походженням, давньою і багатою культурою свого континенту. Зерна, які вони посіяли, проросли у 50-60-ті роки, коли сповнені оптимізму африканські еліти проголошували незалежність своїх країн та творили нові незалежні суспільства.

\section{Омріяна незалежність}

На хвилі здобуття незалежності від європейських метрополій народжується оптимістична публіцистика, яка проявляє себе у політичних промовах провідників новопосталих африканських націй, у літературних творах, які мали виразну публіцистичну складову, навіть у наукових дослідженнях, покликаних реабілітувати африканську культуру. Прикладом останнього можуть бути роботи сенегальського історика та антрополога Шейха Анта Діопа, який обгрунтовував тезу про давнину, багатство і самобутність африканської культури, про «старшинство африканських цивілізацій», пов’язував давній Єгипет із субсахаріальною чорною Африкою, шукав негроїдні риси у знаменитого Сфінкса тощо [5].

\footnotetext{
* Українська інтелігенція у бездержавному ХІХ ст. теж вдавалися до метафори заснулої України, яку треба «розбудити». Зокрема, Олександр Духнович на Закарпатті: «Задуйте сильно і гласно в трубу, ударьте крђпко в тарабан, чтоби потряслися і пробудилися духом» (Въсник, 1850, 1 березня, [цитата за: 2]), Леся Українка у підросійській Україні, творить образ Касандри («Прокинься, Троє! Смерть іде на тебе!»). «Будительська» місія інтелігенції проступає у публіцистичних та художніх текстах Івана Франка [Див. детальніше: 3].
} 
Емоційна домінанта перших років після проголошення незалежності - пафос, кураж, запаморочення від досягнення омріяної свободи, довгожданого звільнення від пут колоніалізму. Африка цього періоду багата на пасіонарних лідерів, які були водночас яскравими політичними діячами та талановитими публіцистами: Джомо Кеніата, Нельсон Мандела, Кваме Нкрума, Патріс Лумумба, згадуваний Леопольд Сенгор. Усі вони на тому чи іншому етапі стали провідниками новопосталих африканських націй. Прем’єр-міністр ДР Конго Патріс Лумумба з оптимізмом дивився у майбутнє: «Творець дав нам цю частку планети, відому під назвою Африканський континент; він належить нам і ми є його єдиними господарями. Наше право зробити цей континент континентом справедливості, закону та миру». Водночас Лумумба «протягає братню руку Заходу» та тим білим, що залишаються в Африці: «Свропейці мають визнати і прийняти ідею, що визвольний рух, у якому ми беремо участь по всій Африці, не спрямований проти них, ані проти їхньої власності, а винятково проти режиму експлуатації та поневолення, який ми більше не хочемо терпіти» [6].

Велике значення для самоусвідомлення африканців мала новопостала африканська література англійською, французькою, португальською мовами. Література відіграє важливу функцію творення національного наративу, героїчного міфу боротьби проти загарбників. Одним із найпомітніших творців цього наративу є кенійський письменник Нгугі Ва Тхіого, який у романі «Пшеничне зерно» анатомує кенійське суспільство зразка останніх років перед здобуттям незалежності та виводить три базові африканські типи:

1) Каранджа, переконаний колаборант, який вважає панування європейців закономірним («Біла людина залишиться тут навіки»). Він розглядає білу людину як силу, «яка створила бомбу і перетворила дикі, порослі чагарниками рівнини у сучасні міста 3 асфальтованими вулицями, мотоциклами і автомобілями, поїздами та аеропланами та будинками, що сягають небес, - і все це за якихось шістдесят років».

2) Кіхіка є прикладом борця за свободу Кенії, бездоганного, жертовного, шляхетного. На нього повинні орієнтуватися нові покоління кенійців зокрема та африканців загалом.

3) Муго - найменш однозначний персонаж, якого терзають сумніви та суперечності. Суспільство хоче бачити його героєм, а він до цієї ролі не готовий. «Адже, знаєш, був момент, коли мені стало байдуже, отримає країна свободу чи ні. Я хотів одного - додому повернутися. Будь-якою ціною! Нехай Кенія дістається білим - все одно!». Це той проблемний тип африканця, будити якого від сну байдужості взялися африканські публіцисти.

Серед інших прикладів публіцистично орієнтованої літератури 1950-х-70-х, i навіть 80-х років - художні тексти південноафриканця Пітера Абрагамса про визволення чорних рабів («Бурський трек»), івуарійця Бернара Дадьє про антиколоніальну боротьбу жителів Берега Слонової Кості («Клемб’є»), бенінця Олімпа Белі-Кенума про презирство білих чужинців до чорного місцевого населення («Африканська історія»), ангольців Артура Карлуша Пестани («Пригоди Нгунги») та Мануеля Руя («П’ятий день незалежності») про геройську боротьбу проти загарбників. Вже 1983 р. зімбабвієць Едмунд Чіпамауга видає дещо графоманський, але патріотичний і типовий для характеризованої епохи роман «Борець за свободу», у якому змальовує зімбабвійську (одну з останніх) версію африканського національного героя, борця за свободу батьківщини. Названі та інші літературні тексти високого, середнього іноді 
низького художнього рівня, здійснили вагомий внесок у конструювання проафриканської картини світу.

Слід відзначити, що ці художні тексти, як правило, не мали расистського характеру, підтвердженням чому були часті позитивні образи білих: фермер Джордж у Чіпамауги, ірландець за походженням, який не просто визнає право народу Зімбабве боротися за свободу, але й бере активну участь у цій боротьбі; Жюльєн із «Африканської історії», здатний шанувати людську гідність чорних людей на шкоду собі.

\section{Нові виклики перед Африкою}

Дуже швидко, однак, ейфорія закінчилася. Виявилося, що колоніалізм нікуди не подівся, а мімікрував, європейці, надавши незалежність африканським народам, не відмовилися від природних ресурсів та дешевої робочої сили з Африки. Президент Гани Кваме Нкрума вже у 1965 р. (через 8 років після проголошення незалежності) писав: «Сутність неоколоніалізму в тому, що держава, яка є його об’єктом, - теоретично незалежна та має всі зовнішні ознаки міжнародного суверенітету. В реальності її економічна система і, відповідно, їі політичний курс визначається ззовні» [7].

Патріс Лумумба, який у перші місяці незалежності ДР Конго зіткнувся з проблемою інспірованого бельгійцями сепаратизму в особливо багатих ресурсами провінціях країни, заявляв: «Конго є суверенною, незалежною і вільною державою 3 тими ж правами, що й Франція, Бельгія, Англія та США. Ми господарі наших власних доль і зробимо з Конго те, що захочемо, а не те, що інші захочуть... Разом 3 нашими людьми ми повинні захищати нашу країну до кінця, незалежно від інтриг і маневрів бельгійських колонізаторів та їхніх союзників. Історія покаже, хто правий» [8]. Харизматичного прем’єр-міністра, який прагнув «перетворити Конго на велику, вільну і процвітаючу націю, на землю свободи і демократії» [9], зрадили і вбили. На зміну шляхетним, жертовним, освіченим лідерам до влади у більшості африканських країн прийшло покоління Сесе Секо Мобуту, Жан-Бедель Бокасса та Іді Аміна, жорстоких, позбавлених принципів диктаторів, які поставили хрест на сподіваннях африканців на краще життя.

У площині художньої літератури це духовне спустошення відображають письменники на зразок Айі Квеі Арма, який у романі «Фрагменти» (1970) береться за типовий для африканської літератури того часу образ інтелігента, який повертається в Африку після кількох років життя і навчання на Заході. Головний герой, Бокко, намагається вписатися у ментальний, соціальний, культурний ландшафт здавалося б рідної йому Гани. На роботу влаштовуються по знайомству або за хабар, транспорт не їздить, лікарні не приймають хворих, журнали не виходять, література не має читачів. Рядового ганця відзначає холуйська запопадливість перед білими іноземцями та доморощеними скоробагатьками. У всіх сферах життя країни - корупція, непотизм і фальш. Зате на рівні формальностей ганська еліта та рядові ганці як правило соромляться всього африканського, місцевих звичаїв, традицій, вірувань, тягнуться до Свропи. Але наслідування західних зразків у політичний, культурний та побутовій сферах - не сутнісне, а фасадне, непослідовне, а тому має характер карикатури африканської країни на саму себе, щоденного трагічного анекдоту, у якому головний герой Бокко так і не зумів знайти собі місця. 
Аналогічні теми розвивають нігерієць Воле Шоїнка в романі «Інтерпретатори» (1964), де молоді люди повертаються із Західного світу в Африку з ініціативами, проектами, готовністю вкладати свою енергію у розбудову Нігерії, але усі їхні починання розбиваються об закостенілу, корумповану систему, яка не терпить ентузіастів, нововведень, модернізацій.

Розчарування новою вільною Африкою навіюють твори таких авторів як конголезець Анрі Лопез (новела «Депутат» виводить образ безпринципного державного діяча, для якого політика - не зорієнтована на суспільне благо діяльність, а спосіб забезпечити собі сите комфортабельне життя та статус), мадагаскарець Арсен Раціфехера (повість «Його гнів», у якій чиновники та спекулянти блокують усяку здорову ініціативу, усяку спробу вивести темних селян з їхнього злиденного становища).

Таку картину виводить колективний африканський письменник вже у перші постколоніальні десятиліття. Наскрізним мотивом літератури та публіцистики цього періоду є розчарування: реальна Африка не відповідала ідеалізованому образу, про який мріяли їхні діди, за який боролися їхні батьки.

Цей період побудований на усвідомленні провідними умами континенту, що 3 формальною політичною емансипацією Африки нічого посутньо не змінилося: політична еліта, як правило, мало чим краща за колоніальні адміністрації, не демонструє стратегічного мислення, а керується особистими інтересами, придушує розвиток соціальних інститутів, демократії та правової свідомості, аби якнайдовше перебувати у привілейованому становищі. Більше того, Африка і далі перебуває в економічній, політичній, культурній, ментальній залежності від західних держав. Камерунський публіцист Жан-П’єр Беколо наголошує, що «Африка є західним винаходом»: «Ми не створили наших країн. Камерун, наприклад - це західна креатура, від його території до його законів. Назва «Камерун», яку ми так і не наважилися поміняти, не пішла від нас. Білі дали нам цю назву, вона походить від Camaroes (креветки) і ми дуже горді носити її сьогодні» [10].

Серед десяти найбільших проблем Африки тоголезький автор Мавуна Кутонін (Mawuna Koutonin) виділяє бідність (за його словами, «Африка - багатий континент, населений бідними людьми»), залежність від зовнішньої допомоги, схиляння перед іноземцями (рабська психологія), нескінченні конфлікти, нерозуміння африканськими елітами макіавелізму західних еліт, науково-технічна відсталість, неадекватне сприйняття світу, менталітет краба, неадекватна картина Африки у світових медіа [11].

Про одну з типово африканських проблем, тотальну корупцію у вищих органах влади, пише ганський публіцист Лорд Аікінс Адусей (Lord Aikins Adusei): «Корупція, немов ракова пухлина, трагічно спустошила африканські суспільства і зробила мільйони людей дуже бідними. Від Південної Африки до Єгипту щупальця корупції досягають всюди. Корупція не має меж. Від кабінетів президентів і прем'єрів до найменших адміністративних урядових відділень - корупція всюди» [12]. Один iз наслідків корупції - чітка соціальна поляризація, в умовах якої вузький елітний прошарок лікується, відпочиває, вивчає дітей та купує нерухомість за кордоном, в той час як народні маси позбавлені елементарних засобів до існування [Див. детальніше: 13].

На початку 2000-х ангольський журналіст Рафаель Маркеш де Мораіш розслідував торгівлю алмазами в Анголі і пов'язані з цим бізнесом порушення прав люди- 
ни. У 2011 році в Португалії він опублікував книгу під назвою «Криваві діаманти: корупція і тортури в Анголі». У книзі детально описані свідчення місцевих жителів про вбивства, тортури, залякування і захоплення земель на території видобутку алмазів. «Що може змусити режим придушувати власний народ, доводити населення до нелюдських умов, в той час як деякі обрані збагачуються через насильство та грабунок спадщини країни? - пише де Мораіш. - Відповідь на ці запитання лежить, зокрема, у згубному характері ангольського панівного класу, корислива поведінка якого нагадує поведінку злочинного угруповання. Ця банда заохочує страх і неуцтво в суспільстві як прийнятні форми соціальної поведінки. Вона збіднює суспільство, корумпує його і жертвує ним із видимим задоволенням, утверджуючи в такий спосіб власну гегемонію над переважною більшістю ангольських громадян» [14, Р. 149].

Дехто з авторитетних африканських публіцистів звертає сповнений надії погляд на Китай, нового гравця на континенті, із яким африканці не мають негативного досвіду взаємодії. Замбійська публіцистка Дамбіса Мойо таким чином трактує китайський фактор: «Ніхто не заперечує, що Китай присутній в Африці заради нафти, золота, міді і всього іншого, що лежить у землі. Але говорити про те, що середньому африканцеві це взагалі не приносить користі, означає брехати, і критики це знають» [15]. Ще далі в апологетиці африкансько-китайської співпраці зайшов Жан-П'єр Беколо: «Нам дуже комфортно разом. Ми обговорюємо речі, які хочемо зробити разом, без прихованої порядку денного, без ідеології, без супремасизму та расизму. І ми це робимо. Те, що пропонують нам китайці, - не китайська культура, а західні технології та сучасність, у якій Захід нам відмовив» [10]. Така позиція дуже популярна в Африці, впродовж десятиліття iï активно розвивають та обгрунтовують патріотично налаштовані публіцисти у різних куточках континенту [Див. детальніше: 16].

Важливо, що значна частина сучасних африканських публіцистів, замість покладати надії на нового китайського патрона, кращого за західного, все більше усвідомлює необхідність відмовлятися від зовнішнього локусу контролю та брати на себе відповідальність за свою долю, а не обмежуватися звинуваченнями на адресу колоніалістів минулого і сучасності. Таку позицію займає згадуваний Рафаель Маркеш де Мораіш: «Сповнені благих намірів ангольські громадяни, особливо молодь, не може покладатися на зовнішню допомогу: у них немає вибору, окрім як розвивати почуття колективного обурення та організовуватися проти систематичних зловживань, які були вчинені проти однієї частини населення, і які є викликом для всього суспільства. Міжнародні економічні інтереси в поєднанні з ресурсами режиму не можуть далі підкорювати найвищу волю цілого народу. Тільки згуртованість серед ангольців та їх солідарність заради загального блага може гарантувати, для майбутніх поколінь, спадок, у якому багатьом ангольцям відмовляли уже протягом тривалого часу, а саме - повагу до людського життя й гідності» [14, Р. 149].

Виступ «Небезпека єдиної історії» Чімаманди Нгозі Адічі, провокаційна стаття «Як писати про Африку» Біньяванги Вайнаіна, публіцистичні тексти Проміса Океке - приклади успішних спроб привернути увагу до іншої Африки, не бідної та голодної, а щасливої та процвітаючої, до Африки, яка впевнено дивиться у майбутнс. Намагання зламати негативні стереотипи про континент - ознака зрілості африканської публіцистичної думки, яка все рішучіше відмовляється від ролі жертви. 


\section{Висновок}

Африканська публіцистична думка як самодостатній феномен сформувалася у 1930-х роках у Парижі. Студенти африканського походження, зокрема Еме Сезер та Леопольд Сенгор, порушили проблематику пробудження та самоутвердження африканців у світі. Публіцистичні тексти, які у тридцяті роки публікували видання L'Etudiant Noir, Revue du Monde Noir, Légitime Défense, стали підгрунтям для масштабнішого антиколоніального дискурсу у перші післявоєнні десятиліття. Боротьба за незалежність африканських народів та успіхи, якими ця боротьба увінчалася (близько п'ятдесяти незалежних африканські держав, які виникли у 1950-ті-80-ті рр.) породили політичну публіцистику із високим градусом незалежницького пафосу, художню літературу із вагомою публіцистичною складовою, яка створює культ героя, борця за свободу, гуманітарну науку, яка реабілітовує африканську культуру на фоні інших. Період загальноафриканського підйому та оптимізму минув, як тільки провідні публіцисти континенту побачили, що проблеми колоніальної епохи не знайшли вирішення, а деякі - навпаки загострилися: колоніалізм нікуди не пішов, просто набув латентного характеру, на зміну пасіонарним лідерам боротьби за незалежність прийшли нові африканські еліти, зазвичай - недалекоглядні, корумповані, позбавлені почуття відповідальності перед суспільством та поваги до закону. Серед можливих варіантів вирішення одвічних проблем свого континенту африканські публіцисти виділяють взаємовигідну співпрацю з Китаєм та опору на власні сили (яка включає розвиток громадянського суспільства, громадських інститутів, здатних контролювати владу та впливати на неї). Популярність першої позиції - свідчення успіхів КНР у вмінні застосовувати soft power, бути привабливою альтернативою Заходу, зокрема - на такому багатому на людські та природні ресурси континенті, як Африка. Наявність другої позиції в африканських медіа - свідчення дорослішання африканських суспільств, уміння не шукати винних серед минулих чи сучасних колонізаторів, а перш за все брати відповідальність за невдачі і провали на себе.

\section{REFERENCES}

1. Césaire A. Conscience Raciale et Révolution Sociale / Aimé Césaire // L'Etudiant Noir. - \#1, mars.

2. Сенько I. Будительство в літературному процесі Закарпаття: всеукраїнський контекст / Іван Сенько // Сучасні проблеми мовознавства та літературознавства . 2010. - Вип. 14. - С. 157-164.

3. Забужко О. Філософія української ідеї та європейський контекст: франківський період / О. Забужко. - К.: Факт, 2006. - С. 72-78;

4. Senghor L. Sedar. Racisme? Non, mais Alliance spirituelle / Leopold Senghor // L'Etudiant Noir. - 1935. - \#3, mai-june.

5. Diop Ch. A. Anteriorité des civilisations nègres, mythe ou vérité historique? / Cheikh Anta Diop. - Paris : Présence Africaine, 1967. - 301 p.

6. Lumumba P. African Unity and National Independence / Patrice Lumumba // Jean Van Lierde ed. Lumumba Speaks: The Speeches and Writings of Patrice Lumumba, 19581961, Boston: Little, Brown and Company, 1972. 
7. Nkrumah K. Neo-Colonialism, the Last Stage of imperialism / Kwame Nkrumah // Available from : goo.gl/AEaiep

8. Lumumba P. Statement at a press conference in Leopoldville / Patrice Lumumba // Available from : goo.gl/q4PZaY

9. Lumumba P. Concluding speech at the All-African Conference in Leopoldville / Patrice Lumumba // Available from : goo.gl/KnjzYK

10. Europe: The view from Africa // This is Africa. - 2015. - May 8. - Available from : goo. gl/oyJC $8 \mathrm{~h}$

11. Koutonin M. Africa's Top 10 Problems / Mawuna Koutonin // At Cradlefin. - 2017. July 28. - Available from : goo.gl/JU6YhN

12. Adusei L. A. Corruption in Africa: A Cancer that won't go away / Lord Aikins Adusei // Modern Ghana. - 2009. - January 25. - Available from : goo.gl/2cpmeo

13. Top African President's Kids Living Large (Eps.12) // «The Break» With Tracy. - 2014. Feb. 10. - Available from : goo.gl/KhQmL7

14. Morais R. M. de. Diamantes de Sangue. Corrupção e Tortura em Angola / Rafael Marques de Morais. - Tinta da China, 2011. - 230 p.

15. Moyo D. Dead Aid: Why aid is not working and how there is another way for Africa / Dambisa Moyo. - Penguin Books, 2011. - 208 p.

16. Мельник Ю. Підступи «китайського злодія» в Африці / Ю. Мельник // Листи до приятелів. - 2016. - 20 лип. - Режим доступу : goo.gl/QYx4Tf 


\title{
THE DEVELOPMENT OF PUBLICISTIC THOUGHT IN THE SUB-SACHARAN AFRICAN COUNTRIES
}

\author{
Iurii Melnyk \\ Ivan Franko National University of Lviv, \\ Generala Chuprynky Str., 49, 79044, Lviv, Ukraine \\ e-mail:melnykiurii@gmail.com
}

The African journalistic thought as a self-sufficient phenomenon has been formed in the 1930s in Paris. Students of African descent, in particular Aimé Césaire and Leopold Senghor, have raised the issue of African awakening and self-affirmation in the world. The journalistic texts published in the 1930s in L'Etudiant Noir, Revue du Monde Noir, Légitime Défense became the basis for a larger-scale anti-colonial discourse in the first post-war decades. The struggle for the independence of the African peoples and the success of this struggle (about fifty independent African states that arose in the 1950s-80s) gave birth to political journalism with a high degree of independence pathos, literature with a significant publicistic component (which includes the cult of a hero, a fighter for freedom), humanitarian science that rehabilitates the African culture in the eyes of the world. The period of general African upsurge and optimism has passed, as soon as the leading publicists of the continent saw that the problems of the colonial era did not find a solution, and some, on the contrary, became aggravated: colonialism did not go away, just became latent, the passionate leaders of the independence struggle have been replaced by the new African elites, usually not far-sighted, corrupt, deprived of sense of responsibility towards society and respect for the law. Among the possible solutions to the eternal problems of their continent, African publicists identify the mutually beneficial cooperation with China and the self-reliance (which includes the development of civil society, public institutions capable of controlling and influencing the governments). The popularity of the first position is evidence of the PRC's success in its ability to use 'soft power', to be an attractive alternative to the West, in particular in such rich of human and natural resources continent as Africa. The presence of the second position in the African media is evidence of the maturity of African societies, their ability to to take responsibility for their failures before acusing colonizers of past or present.

Key words: Sub-Saharan Africa, African Journalism, African Literature, négritude, independence struggle. 